\title{
POLSKI PORTRET METROPOLITY ANDRZEJA SZEPTYCKIEGO. Z MATERIALÓW ARCHIWUM HISTORYCZNEGO WE LWOWIE
}

\author{
SYLWIA WÓJTOWICZ \\ Uniwersytet Wrocławski, Wrocław — Polska \\ ПОЛЬСЬКИЙ ПОРТРЕТ МИТРОПОЛИТА АНДРІЯ ШЕПТИЦЬКОГО. \\ 3 МАТЕРІАЛІВ ІСТОРИЧНОГО АРХІВУ У ЛЬВОВІ \\ СИЛЬВІЯ ВУЙТОВІЧ \\ Вроцлавський університет, Вроцлав - Польща \\ АНОТАЦІЯ. Стаття репрезентує ставлення польської преси 20-30 pp. XX століт- \\ тя до релігійно-політичної діяльності митрополита Андрея Шептицького. Портрет вла- \\ дики, що вимальовується на шпальтах польських газет, — це багатомірний і неодно- \\ значний образ, який характеризується крайніми емоціями, як і епоха, в якій митрополи- \\ ту довелося жити і працювати.
}

\section{METRPOLITAN ANDRIJ SHEPTYTSKYI'S POLISH PORTRAIT (BASED ON THE MATERIALS FROM L'VIV ARCHIVES)}

\author{
SYLWIA WÓJTOWICZ \\ Wrocław University, Wrocław - Poland
}

SUMMARY. The article deals with the attitude of Polish press in the 20-30s of the $\mathrm{XX}^{\text {th }}$ century to Metropolitan Andrei Sheptytskyi's religious-political activity. The portrait of Metropolitan depicted in Polish press is a versatile image characterized by extreme emotions as the very epoch he lived in.

$\mathrm{P}$ róbę odtworzenia portretu wybitnej osobowości, jaką był w nowożytnej kulturze ukraińskiej Metropolita kościoła greckokatolickiego Andrzej Szeptycki należy rozpocząć od krótkiego przywołania biografii, zwłaszcza istotnych wydarzeń związanych z jego działalnością religijno-polityczną. Biografia ${ }^{1}$ bowiem jest tym elementem, który niczym płótno malarskie daje doskonałą podstawą dla zaistnienia tła, na którym umieszczane są barwne relacje prasowe z początku XX stulecia, pojawiają się ostre kontury ważnych informacji oficjalnych oraz światłocienie emocjonalnych, czasem stronniczych komentarzy, przy pomocy których powstaje interesujaccy, wielowymiarowy obraz tak samego Metropolity, jak i epoki, w której przyszło mu żyć. W historię jego rodziny wpisuje się ta sama wielokulturowość, która konstytuowała mikrokosmos otaczającej go rzeczywistości. Był synem Zofii z Fredrów Szeptyckiej i Jana Kantego Szeptyckiego, właściciela majątku w Przyłbicach, we wsi należącej do województwa lwowskiego w Galicji Wschod-

${ }^{1}$ Przywotywane przeze mnie $w$ catym artykule fakty polityczno-religijne dotyczace postaci Metropolity pochodza w znaczacej mierze z biogramu autorstwa R. Torzeckiego. Zob.: Życiorys MetropolitySzeptyckiego, [w:] Źródło elektroniczne: http://andrej.pl/index.php?option=com_content\&task=view\&id=74\&Itemid=35, 09.12. 2011. 
niej. Tutaj też przyszedł na świat w 1865 roku i otrzymał imię Roman. Dopiero wstępując do zakonu w 1892 roku przybrał imię Andrzej. Zmarł we Lwowie w roku 1944. Przystąpienie do zakonnej wspólnoty Bazylianów, a więc zakonu obrządku wschodniego, było powrotem do rodzinnej tradycji, bo choć Szeptycki po kądzieli był wnukiem znanego polskiego komediopisarza Aleksandra Fredry - arcypolonusa - jak mawiał jeden z polskich historyków, to korzenie rodziny jego ojca zakotwiczone były w tradycji ruskiej ${ }^{2}$. Interesująca charakterystykę postaci Metropolity zakreślił przebywający na emigracji hrabia Kajetan Czarkowski-Golejewski w artykule zatytułowanym $O$ metropolicie Szeptyckim. Artykuł drukowany był 33 stycznia 1966 roku w londyńskim tygodniu ,Wiadomości”.

Wbrew nieprzytomnym głosom wielu rodaków zaślepionych nienawiścią do tych, których wzrok nie sięga poza prowincjonalne podwórko szowinizmu, śmiem twierdzić, - pisał autor — że ś. p. [K] siądz metropolita Andrzej Szeptycki był nie tylko duchowym przywódcą narodu ukraińskiego, ale i wielkim obywatelem Polski. Obywatelem w znaczeniu zapomnianego powiedzenia: ,gente Ruthenus natione Polonus”. „Natione Polonus” w znaczeniu, jakie te dwa słowa miały w dawnej Rzeczypospolitej, kiedy słowa Polska i Polak były wyrazicielami przynależności do wielkiej wspólnoty narodów a nie do jednego z wielu narodów tworzących tę wspólnotę. W Rzeczypospolitej byli „natione Polonus” Litwin, Rusin, Ukrainiec, Tatar, Ormianin, Żyd czy Niemiec, potomek Szkotów czy innych emigrantów, którzy z pochodzenia z Polakami nie mieli nic wspólnego.[...] Rodzina Szeptyckich była od wieków rodziną ruską. Ruską w znaczeniu ,gente Ruthenus natione Polonus”, czego dowód stanowiło trzech senatorów polskich i trzech biskupów i metropolitów obrządku greko-katolickiego (Warłaam, Atanazy i Lew), poprzedników Andrzeja na stolcu metropolitalnym, z których Atanazy w 1727 a Lew w roku 1778 byli jednocześnie metropolitami kijowskimi $[\ldots]^{3}$.

Szeptycki przechodząc na unię przeszedł zatem na stronę przodków, a z czasem na tyle mocno zrósł się z narodem ruskim (ukraińskim), że już jako biskup, a potem Metropolita stał się niekwestionowanym rzecznikiem jego interesów przede wszystkim religijnych, ale również politycznych, społecznych, kulturowych. Był gorącym zwolennikiem powstania państwa ukraińskiego i czynił ku temu wszelkie starania. Podejmował jednak swą niełatwą misję ,przywódcy duchowego" i politycznego na początku XX stulecia, a więc, jak słusznie pisał Golejewski w tym „,tragicznym okresie przekształcania się lokalnych trudności współżycia w kraju o mieszanej narodowo ludności w konflikt narodowościowy". Żywym świadectwem reakcji opinii publicznej na najważniejsze wydarzenia i sytuację polityczną w Galicji Wschodniej, w tym również poczynania Metropolity Szeptyckiego były artykuły czołowych, zwłaszcza w latach 20. i 30. XX stulecia czasopism polskich. Należał do nich m. in.: dziennik „Kurier Lwowski” (1883-35) — pismo o charakterze informacyjno-politycznym związane z ruchem ludowym, jak również początkowo niezaangażowany politycznie dziennik ogólnokrajowy wydawany w Krakowie w latach 1910-1939 zatytułowany „Ilustrowany Kurier Codzienny”. Wiele komentarzy odnaleźć można w wydawanym od 1895 roku we Lwowie „Słowie Polskim” — organie prasowym Narodowej Demokracji. Wspomnieć należy także „Gazetę Warszawską”

${ }^{2}$ Zob.: Z. Szeptycka, Wspomnienia z lat ubiegłych, do druku przygotował, wstępem i przypisami opatrzył Bogdan Zakrzewski, Wrocław 1967; B. Zakrzews ki, Fredro i Fredrusie, Wrocław 1974; Ślaskie przygody Aleksandra Fredry, Wrocław 1991; 1856 czas kiedy Fredro chciat przeprowadzić się na Ślask.

3 K. Czarkowski-Golejewski, O metropolicie Szeptyckim, [w:] „Wiadomości”, Londyn 30.01.1966, s. 2 . 
(od 1918 roku organ Narodowej Demokracji, który w roku 1935 został zakazany przez władze sanacyjne za zbyt prawicowe poglądy). Wiele faktów od 1920 roku relacjonował dziennik „Rzeczpospolita”, będący do wybuchu II wojny światowej organem konserwatywnego Stronnictwa Chrześcijańsko-Narodowego. Na uwagę zasługuje „Czas” - czasopismo wydawane przez krakowskich konserwatystów (Stańczyków, a później Stronnictwo Prawicy Narodowej) oraz wspierany przez czynniki rządowe „Biuletyn Polsko-Ukraiński” (1931-1938). Na łamach tego ostatniego, swoje artykuły publikowali zarówno polscy, jak i ukraińscy publicyści szukający nici porozumienia w rozwiązywaniu trudnych polsko-ukraińskich kwestii. Działalność pasterska Metropolity nie uchodziła oczywiście uwadze dziennikarzom czasopisma o charakterze religijnym, zatytułowanym „Polak Grekokatolik”. Swój udział w dyskusji miała też prasa polska ukazująca się za granica, np. „Amerykańskie Echo” — gazeta amerykańskiej polonii wydawana w Toledo, w Ohio.

W trudnych czasach politycznego zamętu, dochodzenia do głosu najgroźniejszych ideologii XX wieku - nacjonalizmu i bolszewizmu oraz wzajemnie wykluczających się interesów narodowych i społecznych na spornych ziemiach Galicji Wschodniej tożsamościowe wybory Andrzeja Szeptyckiego oraz jego aktywne działania na rzecz narodu ukraińskiego, niejednokrotnie spotykały się z ostrą krytyką, czy wręcz zarzutem zdrady. Najpierw narodu polskiego, a po utworzeniu w 1918 roku Państwa Polskiego - polskiej racji stanu. Za przykład może posłużyć treść artykułu z „Ilustrowanego Kuriera Codziennego" o intrygującym tytule Kto zacz? z 29 września 1920 roku.

Metropolita hr. Szeptycki, rezydujący we Lwowie, słynie ze swej nienawiści do Polski. Uczucia metropolity to jego własność prywatna. Dopóki nienawidzi nas platonicznie możemy to wytrzymać. Ale metropolita lwowski zaczyna działać. Depesze doniosły, że wyjeżdża do Anglii w sprawie starań „o niepodległość Galicji Wschodniej”. Metropolita Szeptycki jest obywatelem Rzeczpospolitej Polskiej. Obywatel, który działa przeciw własnemu państwu popełnia zdradę stanu. [...] Czy obywatel hr. Szeptycki posiada przywilej oficjalnego działania przeciwko Polsce? ${ }^{4}$

Wyraźne zaniepokojenie strony polskiej wywołał wyjazd Metropolity do Rzymu, który odbył się w grudniu 1920 r. Andrzej Szeptycki miał wówczas złożyć raport papieżowi Benedyktowi XV z bieżących spraw religijnych zawiadywanego przez siebie Kościoła i jednocześnie szukać poparcia dla sprawy niepodległości swego narodu. Do Rzymu udał się ponadto po nowe wytyczne w sprawie dalszej działalności Cerkwi. Jego działalność religijna również nie uszła dziennikarskiej uwadze. 3 listopada tego samego roku „Rzeczpospolita” w artykule zatytułowanym Misja metropolity Szeptyckiego donosiła:

Dziś [maja] się rozpocząć obrady biskupów ruskich w sprawie reform cerkwi grecko-katolickiej, które wywołały wśród duchowieństwa ruskiego wielkie naprężenie. Podobno ma być również omawiana sprawa propagandy katolickiej na Ukrainie, którą metropolita Szeptycki zamierza rozpocząć w większym stylu. Z innej strony otrzymujemy informację, że w sferach ukraińskich toczy się żywa wymiana zdań o sprawie mandatu politycznego, jaki ma otrzymać metropolita Szeptycki od galicyjsko-ukraińskich partii odnośnie do reprezentowania Ukraińców galicyjskich za granica. Jak wiadomo metropolita Szeptycki wybiera się do Rzymu, a podobno i do Londynu. Otrzymał już nawet od władz polskich paszport na 6 miesięcy na wyjazd za granice, gdzie rozpocznie wrogą nam akcję

${ }^{4}$ Kto zacz?, [w:] „Ilustrowany Kurier Codzienny”, Kraków 29.09. 1920, [w:] ЦДІА України, м. Львів, фонд 358, опис 1, справа 32.

${ }^{5}$ Misja metropolity Szeptyckiego, [w:] „Rzeczpospolita”, 3.11.1920, [w:] Niebezpieczni rybacy, „Amerykańskie Echo”, 4.09.1921, [w:] ЦДІА України, м. Львів, фонд 358, опис 1, справа 32. 
Podczas wspomnianej podróży zagranicznej Arcybiskup Szeptycki interweniował u przedstawicieli Ententy na rzecz ZURL i niewłączania Galicji Wschodniej do Polski. Poszukiwał też pomocy finansowo-materiałowej w celu odbudowy ziemi galicyjskiej ze zniszczeń powstałych po I wojnie światowej (1914-18) oraz wojnie polsko-ukraińskiej (1918-19). Swoją misję próbował realizować głównie w Rzymie, ale odwiedził również Paryż, Belgię, Holandię, Stany Zjednoczone, ośrodki ukraińskie w Brazylii i Argentynie. Jego wizyty miały przede wszystkim charakter duszpasterski. Władyka jednak nie zapominał o sprawie ukraińskiej, której ogromnie potrzebne było poparcie innych krajów. Negatywna ocena jego działań religijno-politycznych pojawia się w niedzielnym wydaniu polonijnego czasopisma „Amerykańskie Echo" 4 września 1921 roku. Autor publikacji posługujący się jedynie inicjałem „K.” w atmosferze podejrzliwości i spiskowej teorii dziejów, w sposób niezwykle obrazowy, aczkolwiek tendencyjno-infantylny kreśli, a właściwie rozprawia się z religijną polityką Watykanu na ziemiach polskich. Przyrównuje sytuację panującą w tzw. Małopolsce Wschodniej do zasad agresywnego rybołówstwa, nie szczędząc politycznej łajanki Papieżowi, jego wysłannikom, niektórym duchownym polskim oraz, co oczywiste, Metropolicie Szeptyckiemu.

Przytoczmy tylko niektóre ogólnie znane nazwiska watykańskich rybaków, którzy chcą zobaczyć jak najprędzej w swoich niewodach nie sielskie ryby, raki, perły majątków ruchomych i ziemskich, jej złoto i wszelkie mienie, sumienie i wolność obywatelska, ale Polskę całą, jako państwo, aby ją mogli hurtownie sprzedać na rynku światowym, bo taki mają nakaz od prezydenta trustu, od chytrego i zimnego jak lód Benedykta. Łowią co się da bezkarnie i broją wybitni watykańscy rybacy, do których w pierwszym rzędzie zaliczają się: Ratti i Ogno [...] Pomagają im w tej zgubnej dla Polski robocie nie mnie dzielni krajowi, polscy najemnicy i agenci trustu watykańskiego: ksiądz Lutosławski, arcybiskup Teodorowicz, Kardynał Dalbor i arcybiskup kniaź Szeptycki. Ten ostatni zwłaszcza występuje z całą bezczelnością już nie w roli rybaka, wyławiającego dla trustu watykańskiego umysłowość polska, dobre imię Polski i polskie skarby, ale w roli otwartego szpiega i zdrajcy polskiej sprawy.

Wyzyskując w Polsce bezwstydny przywilej wyznaniowego rybołówstwa dla trustu watykańskiego, objeżdża bezkarnie wschodnie kresy Rzeczpospolitej Polskiej, Rosję, ba nawet Kanadę, zostawiając wszędzie zdradliwe dla Polaków ukraińsko-watykańskie sidła do spółki z prezesem trustu, czyli papieżem. Prowadzi on dalej robotę zapoczątkowaną przez Austriaków i Niemców, którzy pogrzebali świętą Czerwoną Ruś w obrębie granic Polski, a przez czarodziejskie sztuczki, na zgubę Polsce i bratniej Rusi, wywołali we wschodniej Galicji ducha „Ukrainy” i koniecznie chcieli oblepić go w ciało ${ }^{6}$.

W artykule znajduje swoje odzwierciedlenie również pogląd reprezentowany przez znaczną część polskiej opinii publicznej z przełomu XIX-XX wieku o odrębności kulturowej i narodowej Rusinów (Ukraińców) zamieszkujących Ruś Czerwoną (Galicję Wschodnią) i Ukraińców zamieszkujących tereny Ukrainy Naddnieprzańskiej. [...] Ukraina była u kraju granic Rzeczpospolitej, nad Dnieprem, ale nigdy na Podolu, ani na Wołyniu, ani w Galicji Wschodniej, czyli w dzisiejszej wschodniej Małopolsce. Nie poświadczy tego żadna historia. Czerwona Ruś, która od wieków do Polski lgnęła, aż w końcu przylgnęła w skutek pokrewieństwa panujących tam rodów, była krajem kulturalnym, podczas gdy Ukrainą zwano „dzikie pola" Daleko nad Dnieprem [...]. Nikt też mądry nie szukał na Ukrainie kultury,

${ }^{6}$ Ibidem. 
bo jej tam nie było, ani żadne pomniki nie przeszły w spadku do potomności. Wspólność obrządku religijnego (wschodniego) ludów mieszkających za po San, nie stanowi jeszcze żadnego dowodu wspólności narodowej

Na poparcie swojej tezy autor publikacji przywołuje przykłady różnych narodów europejskich, które mają ten sam obrządek religijny i nie stanowią jedności narodowej. W tym kontekście odnosi się wprost do osoby Metropolity: Jeżeli arcybiskup kniaź Szeptycki, chce łowić dusze ukraińskie, niech idzie nad Dniepr, niech się postara o kontrakt dzierżawny u Lenina i Trockiego, ale nie na wschodnich kresach Polski, nie w Kanadzie. Niechaj nie nadużywa przy tym połowie powagi polskiego państwa, polskiego imienia, bo to oszustwo, bo to czyn wysoce karygodny wobec polskiego i Rusińskiego narodu. Komu źle na pięknej ziemi czerwono-ruskiej, kto nie czuje się Rusinem, ale Ukraińcem [...] ten powinien czym prędzej przenieść się nad Dniepr na Ukrainę [...].

Arcybiskup kniaź Szeptycki mąci wodę we wschodniej Małopolsce, czyli na Rusi Czerwonej, oszukuje Polaków i Rusinów, twierdząc, że w tej mętnej wodzie są ukraińskie ryby, które on może łowić wszędzie, gdzie mu się podoba i jak mu się spodoba, na mocy powszechnego prawa dzierżawy duchownego rybołówstwa w obrębie granic Rzeczpospolitej. A przecież każdy przeciętny, zdrowo myślący Polak i Rusin wie to dobrze, do czego zmierza połów kniazia Szeptyckiego, że do oderwania Rusi Czerwonej od Polski i zdania jej w przyszłości na łaskę Rosji, podobnie jak to kiedyś postapił Chmielnicki z Ukrainą. Jako zapłatę za dokonanie takiej roboty, bolszewicki rząd rosyjski udzieli chętnie trustowi watykańskiemu koncesji na połów dusz w obrębie Rosji, ze szczególnym, uwzględnieniem Ukrainy, gdzie rybacy założą swoja główną siedzibę. [...] Wobec takie stanu rzeczy podziwiać należy pobłażliwość Polski, która na swoich wodach cierpi jeszcze ciągle tych niebezpiecznych rybaków i nie zerwie kontraktu z watykańskim trustem. [...] Takich cudzoziemskich rybaków wyrzucono by dawno za dziesiątą granicę. [...] Zaś takich wichrzycieli jak arcybiskup kniaź Szeptycki posłano by na wygnanie lub do więzienia ${ }^{8}$.

Podczas zagranicznej misji Metropolita Szeptycki nie osiagnął pożądanych rezultatów politycznych. Polskie MSZ i wywiad interesowały się żywo jego podróżami i wizytami. Po powrocie pod koniec września 1923 roku został zatrzymany na granicy polsko-czeskiej, skąd został skierowany na pewien czas do Poznania. Również i ten fakt szeroko odnotowywała prasa polska. 25 sierpnia 1923 roku „Czas”, powołując się na prywatną relację telefoniczną z dnia poprzedniego (Dziedzice, 24 sierpnia), zamieścił na łamach gazety informację pod niejednoznacznym tytułem Aresztowanie X. Szeptyckiego?

Wczoraj nad ranem rozeszła się sensacyjna pogłoska o aresztowaniu metropolity Szeptyckiego, według której przy przeglądaniu pociagu pospiesznego Wiedeń Lwów o godz. 1 w nocy, w wagonie sypialnym spostrzeżono X. Szeptyckiego, jadącego ze swym sekretarzem X. kanonikiem Kaniowskim do Lwowa. Ponieważ, jak wiadomo, ministerstwo spraw wewnętrznych zabroniło X. Szeptyckiemu wstępu w granice Polski, przeto policja państwowa wezwała go do opuszczenia wagonu. $\mathrm{X}$. Szeptycki wezwania nie usłuchał, a sekretarz jego oświadczył w jego imieniu, że metropolita jest ciężko chory i absolutnie nie może opuścić wagonu. Wtedy policja odczepiła od pociagu wagon sypialny, w którym znajdował się X. Szeptycki; innych podróżnych usunęła $\mathrm{z}$ niego, a pozostawiła w nim tylko X. Szeptyckiego i jego sekretarza X. Kaniowskiego, poczem wóz ten ustawiono na bocznym torze

\footnotetext{
${ }^{7}$ Ibidem.

${ }^{8}$ Ibidem.
} 
i obstawiono posterunkami policji. Komenda policji zwróciła się równocześnie do Warszawy o dalsze dyspozycje?

Wydarzenie poznańskie, określane w prasie także jako „incydent poznański” odbiło się szerokim echem również $w$ innych dziennikach. Opinia publiczna wkrótce zainteresowana była datą powrotu Andrzeja Szeptyckiego do Pałacu Metropolitalnego. 29 sierpnia tego samego roku w "Słowie Polskim” odnajdujemy nagłówek: Kiedy Metropolita Szeptycki wróci do Lwowa? „Słowo...” powołując się na Agencję Wywiadu cytowało „Gazetę Warszawską”, która, jak pisano, kategorycznie stwierdzała, że metropolita Szeptycki nie jest internowany i znajduje się na zupełnej swobodzie przez nikogo nie strzeżony. Po porozumieniu z komisarzem rządowym metr. Szeptycki sam zdecydował się udać do Poznania. Sprawa powrotu metr. Szeptyckiego była już na drodze do uregulowania na płaszczyźnie pertraktacji rządu z Watykanem. Przyjazd metropolity pertraktacje te przerwał, zmuszając rząd do podjęcia nowych kroków politycznych. Sprawa metrop. Szeptyckiego będzie załatwiona zadowalająco z chwila, gdy rząd uzyska zapewnienie ks. metr. Szeptyckiego o jego zupełnej lojalności wobec Państwa Polskiego z uwzględnieniem faktu, że Małopolska Wschodnia jest częścią organiczną Państwa Polskiego ${ }^{10}$.

Kolejną wiadomością prasowa na ten temat była informacja przywoływana w „Słowie...” za Polską Agencją Telegraficzną, która opierała się na wiadomościach z „Rzeczpospolitej” :

Biskup przemyski obrządku gr.-kat. ks. Kucyłowski, który w ostatnich dniach bawił u metropolity Szeptyckiego, w powrocie z Poznania do Lwowa był na dłuższej audiencji u pana ministra spraw wewnętrznych Kiernika, celem omówienia sprawy ewentualnego powrotu metropolity do Lwowa. P. minister podkreślił jeszcze raz, że powodem zatrzymania metropolity była wyłącznie troska o niewywoływanie niepokojów. Metropolita wjechał do Poznania na własne życzenie. P. minister zaznaczył konieczność obustronnego wpływania na uspokojenie umysłów. Ks. biskup Kucyłowski i dr Gwozdecki stwierdzili wobec p. ministra, ze metropolita korzysta z zupełnej wolności , otoczony jest należytą opieką lekarską i szacunkiem należnym jego godności ${ }^{11}$.

W dalszych doniesieniach prasowych na temat możliwości pozytywnego zakończenia przymusowego pobytu Metropolity w Poznaniu czytamy:

Warszawa PAT [Polska Agencja Telegraficzna]. Przebywający w Poznaniu metropolita Szeptycki zwrócił się do p. Prezydenta Rzeczpospolitej z prośbą u dzielenie mu audiencji. Jak się dowiadujemy p. Prezydent po porozumieniu się z rządem polecił kancelarii cywilnej zawiadomić metropolitę Szeptyckiego, że audiencja będzie mu udzielona. Ponieważ metropolita w prośbie swojej zaznaczył, że wobec stanu choroby nie będzie mógł przybyć do Warszawy przed upływem 4 tygodni, przeto termin audiencji zostanie ustalony później ${ }^{12}$.

Dzienniki na bieżąco donosiły o wydarzeniach związanych z osobą Metropolity, cytując niejednokrotnie warszawską Agencję Wywiadu. W ten sposób informowano o „nieszczególnym” stanie zdrowia Władyki lub planowanych w niedługim czasie działaniach:

\footnotetext{
${ }^{9}$ Aresztowanie X. Szeptyckiego?, „Czas”, 25.08.1923, [w:] ЦДІА України, м. Львів, фонд 358, опис 1, справа 32.

${ }^{10}$ Kiedy Metropolita Szeptycki wróci do Lwowa?, [w:] „Słowo Polskie”, 23.08.1923, [w:] ЦДІА України, м. Львів, фонд 358, опис 1, справа 32.

${ }^{11}$ Ibidem.

${ }^{12}$ Przed zlikwidowaniem incydentu z metropolita Szeptyckim, [w:] „Słowo Polskie”, 13.09.1923, [w:] ЦДІА України, м. Львів, фонд 358, опис 1, справа 32.
} 
AW powołując się na „Gazetę Warszawską” podała, że Metropolita Szeptycki na audiencji u Prezydenta Rzeczpospolitej, która odbyć się ma w najbliższym czasie wygłosi przemówienie, w którym wyrazi swój stosunek do Państwa polskiego. [...] audiencja ta i złożona przy tej sposobności deklaracja zakończyć ma incydent z Metropolitą Szeptyckim. [...] metropolita przebywający nadal w szpitalu w Poznaniu polecił Kurii metropolitalnej we Lwowie ogłosić swój list pasterski do duchowieństwa i wiernych datowany z Rzymu. Sprawy stosunku swego do Państwa polskiego dotyka metropolita w słowach: „Wielką cnotą chrześcijanina dopatrywać się wszędzie woli Boga”. Metropolita wzywa do oddania cesarskiego cesarzowi, a co boskiego Bogu; cytuje sw. Pawła, który polecał pokorne poddawanie się wszelkiej władzy, gdyż nie ma takiej, któryby nie pochodziła od Boga ${ }^{13}$.

W doniesieniach prasowych na temat Arcybiskupa Szeptyckiego nie zabrakło również vox populi. 8 październia 1923 roku w „Słowie Polskim” odnajdujemy komentarz sytuacji politycznej oraz roli jaką w owym czasie Władyka odgrywał.

Podały dzienniki wiadomości, że ksiądz Metropolita Szeptycki na audiencji w Spale u Pana Prezydenta Rzeczpospolitej Wojciechowskiego złożył oświadczenie swej lojalności wobec Państwa Polskiego. Niezawodnie nastąpi wkrótce objęcie urzędu w arcybiskupstwie lwowskim. Należy więc rozpatrzeć się w nowej sytuacji, którą ten fakt stworzy.

Nie ma powodu dalej patrzeć z nieufnością w szczerość zamiarów ks. Arc. Szeptyckiego, że dla dobra powierzonej sobie archidiecezji będzie się starał działać w porozumieniu z władzami państwowymi.

Stosunki, które stworzyły wojny, toczące się tak długo na terenie tego kraju, pozostawiły wielkie zniszczenie w każdym kierunku, moralnym, kulturalnym i materialnym. $[\ldots]$

W takich warunkach powinny ustać spory i zaognienia narodowe czy partyjne, a kto pragnie dobra doczesnego i zbawienia dla obywateli tego Państwa, czy on Polak czy Rusin - powinni sobie podać ręce do osiagnięcia tego celu, który wyjdzie na chwałę Bożą i dobro Rzeczpospolitej i każdego poszczególnego obywatela.

Przekonany jestem, że w przeważnej części ludności takie są pragnienia. W zgodnym pożyciu budować i naprawiać, co wojna zniszczyła. Ufajmy, że Arcypasterz przybywający do swej diecezji wraz z podległym sobie duchowieństwem przyświecać będą w takim usiłowaniu, a i w nas wszystkich mieszkańcach tej części Polski, znajdą poparcie i pomoc ${ }^{14}$.

W istocie, po ,incydencie poznańskim” Metropolita powrócił do Lwowa, gdzie zajął się sprawami organizacyjnymi Cerkwi grekokatolickiej. Działalność polityczna bowiem nigdy nie przysłaniała mu problemów religijnych. Zawsze podkreślał, że jest przede wszystkim księdzem, chrześcijaninem i z tej perspektywy odbierał otaczająca go rzeczywistość. W życiu polityczno-społecznym starał się zachowywać stanowisko ponadpartyjne. Sympatyzował jednak z ukraińskim ruchem organicznym (UNDO), ale sam, jak się wydaje, przygotowywał stopniowo odrodzenie ruchu chadeckiego w różnych jego formach organizacyjnych. Był przeciwnikiem ekstremalnego ruchu nacjonalistycznego. Nie zgadzał się w zasadzie na przynależność księży do OUN, chociaż też wyraźnie nie zabraniał im takiej współpracy. Władyka publicznie występował przeciwko terrorowi, zwłaszcza w jego krwawej formie. W 1934 roku o jego ostrej krytyce niegodnych działań terrorystycznych donosiła m.in. „Gazeta Warszawska” . 7 sierpnia tego roku lwowski korespondent „Gazety...” pisał:

${ }^{13}$ Ibidem.

${ }^{14}$ Po powrocie Metropolity, [w:] „Słowie Polskim”, 8.10.1923, [w:] ЦДІА України, м. Львів, фонд 358 , опис 1 , справа 32. 
Enuncjacja „Unda” wydana przed niedawnym czasem, w związku z sytuacją i atmosfera, jaka wytworzyła w Polsce, a przede wszystkim w Małopolsce Wschodniej, „Organizacja Ukraińskich Nacjonalistów” (OUN), przebrzmiała jakeśmy to przewidzieli, bez echa; ba w ślad za nią poszło jej znieczulenie przez mord dokonany ręka członka OUN na osobie dyrektora ruskiego gimnazjum we Lwowie Babija. Po tym zbrodniczym czynie zapowiadano drugą enuncjację „Unda” [...] Tymczasem zamiast enuncjacji „Unda” ukazał się list publiczny metropolity Szeptyckiego, napisany w Podlutem, w letniej rezydencji tego czołowego męża kościoła grecko-katolickiego w Polsce, z którego opinią liczy się starsze społeczeństwo ruskie. List ten jest pewnego rodzaju sensacją i zostanie prawdopodobnie wyzyskany przez zainteresowane czynniki dla odpowiednich celów.

Podnieść należy, że metropolita Szeptycki od dłuższego już czasu nie położył swego podpisu na enuncjacji (oświadczeniu), mającej charakter polityczny. Obecny przeto list świadczy o powadze sytuacji , jaka się na gruncie Małopolski Wschodniej, dzięki zbrodniczej taktyce OUN wytworzyła. [...] List jest silny i odczekać należy skutków. Żałować tylko należy, że pokazał się on dopiero po zamordowaniu ,[U]kraińca" Babija, że nie ujrzał światła po pierwszych mordach terrorystów „ukraińskich”, dokonanych na polskich obywatelach przed rokiem, dwoma, trzema laty, ze autor nie ustosunkował się do tego łańcucha zbrodni dokonanego na mieniu państwa i obywateli polskich. List pokazał się, dopiero, gdy przelał się już puchar po za brzegi.

Dobrze, że się ukazał. [...] śledzić będziemy skutków listu i cieszyć się będziemy, gdy nie pozostanie on tylko dokumentem papierowym ${ }^{15}$.

Jak widać, prasa polska domagała się stanowczej i ostrej krytyki aktów terrorystycznych, których coraz częściej po 1920 roku dopuszczała się w Galicji strona ukraińska w starciu z żywiołem polskim. W istocie, Szeptycki w tej kwestii reprezentował dużą ostrożność. Inną rzeczą jest, że polska strona czasem zbyt głośno i natarczywie domagała się głosu potępienia. Trudne politycznie położenie Metropolity, które z pewnością można nazwać Antygońskim tłumaczy w swych wspomnieniach poslki publicysta i dyplomata, hrabia Jan Stanisław Łoś: ,,[zostawszy] hierarchą unickiej cerkwi, a później jej głową i przekonawszy się, że — o ile nie dokona stanowczego wyboru między zwaśnionymi narodowościami - nie zdoła pozyskać zaufania wyznawców powierzonej sobie cerkwi, metropolita Szeptycki przekroczył stanowczo i nieodwołalnie Rubikon i całym swym późniejszym życiem, aż do przede dnia śmierci nie zawahał się na raz obranej drodze w służbie narodowego Kościoła ukraińskiego. Tego mu Polacy nie wybaczyli. Nie rozumieli, że minęły czasy, gdy można było stanąć jako rozjemca między powaśnionymi narodami, zmuszając je swą powagą do odrzucenia oręża. Rozczarowanie Polaków (mówimy wyłącznie o zamieszkałych w dzielnicy) przemieniło się z biegiem czasu w nienawiść, której objawy niejednokrotnie, a właściwie bardzo często przekraczały nakreślane przez polityczny rozsądek granice. Metropolita zdał sobie z tej nienawiści sprawę, nie uląkł się godzących w niego pocisków i... zaciął się w swym oporze, posuwając się niejednokrotnie zbyt daleko w wykazywaniu, że wybór, jaki dokonał jest nieodwołalny"16.

${ }^{15}$ Enuncjacja metropolity Szeptyckiego (Od własnego korespondenta „Gazety Warszawskiej”), „Gazeta Warszawska”, 07.08.1934, [w:] ЦДІА України, м. Львів, фонд 358, опис 1, справа 32.

${ }^{16}$ J. S. Ło ś, Pamiętnik, tekst pisany w 1972, niepublikowany, s. 82-83. Wspomnienia Stanisława Łosia nie ukazały się jeszcze w formie oficjalnej publikacji. Fragment ich treści (rozdziału zatytułowany Sprawa ukraińska) został mi udostępniony przez syna publicysty — dr inż. Marka Łosia. Cytaty podaję $\mathrm{w}$ oryginalnej wersji z małymi poprawkami natury interpunkcyjnej czy gramatycznej. 
Rok 1934 obfitował w coraz trudniejsze i bardziej krwawe kontakty polskoukraińskie, co zaowocowało wieloma krytycznymi tekstami prasowymi również na temat Metropolity. W tym samym roku jednak 14 października w piśmie finansowanym przez II Odział Wojska Polskiego, tj. w „Biuletynie Polsko-Ukraińskim” ukazał się artykuł przeczący negatywnej tendencji. Autor publikacji (M. Andrusiak) zatytułowanej Szeptyccy szeroko opisuje historię rodu Szeptyckich oraz dokonania Ekscelencji Andrzeja. W podobnym, pozytywnym tonie utrzymana była publikacja z 1939 roku, pomieszczona w dwutygodniku „Polak Greko-Katolik” w 40 rocznicę święceń biskupich Władyki oraz 35 rocznicę wydania znamiennego listu pasterskiego Do Polaków obrzqdku greckiego (1904). Szeptycki z całą mocą podkreślał w nim swoje oddanie wszystkim wiernym kościoła greckokatolickiego, niezależnie od narodowości, której byli przedstawicielami. Jak wielkiej wagi były to słowa, świadczy treść artykułu: [...] wierni grekokatolicy narodowości polskiej, ukraińskiej, węgierskiej, ruskiej, słowackiej itd. wezmą uroczysty udział w radosnych uroczystościach ku czci wielkiego duszpasterza naszej grekokatolickiej cerkwi. Nie my powołani jesteśmy do oceny dorobków Jego świątobliwego życia. Historia oceniać będzie wielki ogrom jego pracy. Podkreślić musimy, że wielki ofiarnik służby Chrystusowej dał nam wiernym grekokatolikom nauki o wartościach nieprzemijających. Wydając list pasterski do Polaków grekokatolików - Metropolita Szeptycki Andrzej wyznaczył na wieki drogowskazy, które obowiązywać będą w naszej cerkwi. Wskazał on, że św. Cerkiew ta nie może być związana z jednym tylko narodem. Może się rozwijać jako cerkiew powszechna ${ }^{17}$.

Zarysowujący się w niniejszym, siłą rzeczy niepełnym, przeglądzie artykułów prasowych portret Metropolity Szeptyckiego wymyka się, jak widać, łatwej ocenie. Obraz tego czołowego ukraińskiego męża stanu jest wielowymiarowy i trudny do jednoznacznej charakterystyki, podobnie jak epoka, w której oddawał swą kapłańską posługę. Z racji sprawowanego wysokiego urzędu oraz działalności nie tylko religijnej, ale i politycznej, społecznej, kulturalnej, Szeptycki dokonywać musiał bardzo trudnych decyzji, które często przysparzały mu wrogów, zwłaszcza w kraju zamieszkiwanym przez narody uzurpujące sobie prawo do tej samej ziemi. Stojąc po stronie ukraińskiej, narażał się niejednokrotnie polskiej opinii publicznej. Dlatego wśród wielu polskich publikacji zgromadzonych w zasobach Archiwum Historycznego we Lwowie dominują te, które z dużą dozą krytycyzmu odnoszą się do postaci Władyki. Jednak i tutaj odnaleźć można wypowiedzi nieodmawiające Metropolicie waloru wyjątkowości i zasług dla trudnego polsko-ukraińskiego porozumienia. O tonie wypowiedzi publicystycznej w dużej mierze decydowały sympatie polityczne czasopism, w których kreślony był jego portret.

${ }^{17}$ Jubileuszowe uroczystości ku czci J. Eks. Metr. Szeptyckiego, [w:] „Polak Greko-Katolik”, 15.06. 1939, nr 11, s. 7. 